\title{
TERAPI BIRTHING BALL UNTUK MENGURANGI NYERI KALA I PERSALINAN PADA IBU BERSALIN DI RSUD KOTA MATARAM
}

\author{
Indriyani Makmun'), Rizkia Amilia²), Ana Pujianti Harahap1), Desi Rofita2), \\ Nurul Qamariah Rista Andaruni ${ }^{3)}$, Biantari Alika Maharani' ${ }^{2}$, Mifanatul Khaira ${ }^{2)}$

\begin{abstract}
1)Program Studi Profesi Bidan, Fakultas Ilmu Kesehatan Universitas Muhammadiyah Mataram, Mataram, NTB 2)Program Studi S1 Kebidanan, Fakultas IImu Kesehatan Universitas Muhammadiyah Mataram, Mataram, NTB ${ }^{3)}$ Ruang Bersalin, RSUD Kota Mataram, Mataram, NTB.
\end{abstract} \\ Corresponding author : Indriyani Makmun \\ E-mail : ndry.ani88@gmail.com
}

Diterima 15 November 2021, Disetujui 17 November 2021

\begin{abstract}
ABSTRAK
Birthing ball merupakan salah satu metode active birth menggunakan bola pilates yang membantu ibu inpartu kala I. Penggunaan bola pilates dengan melakukan gerakan seperti duduk dibola dan bergoyang-goyang, membuat kemajuan persalinan, memberikan rasa nyaman dan, serta meningkatkan sekresi endoprin disebabkan kelenturan dan kelengkungan bola merangsang reseptor dipanggul. Tujuan dari pengabdian masyarakat ini adalah memberikan penyuluhan dan pelatihan tentang birth ball. Metode yang digunakan antara lain ceramah/penyampaian materi menggunakan leaflet, praktikum atau pelatihan langsung kepada peserta serta tanya jawab guna mendukung pengetahuan ibu tentang terapi birthing ball. Hasil dari kegiatan pengabdian dibuktikan dengan keaktifan peserta dalam kegiatan ini, pelaksanaan kegiatan telah mampu meningkatkan pengetahuan ibu bersalin dalam mengurangi nyeri pada kala I persalinan, dapat mengelola rasa nyeri saat kontraksi dan ketidaknyaman ibu seperti rasa cemas berlebih dan mengelola pernafasan serta dapat mengurangi sakit punggung, sesak nafas. Hasil kegiatan ini sangat berdampak positif pada proses persalinan ibu yang lahir dengan normal atau pervaginam tanpa adanya intervensi dilakukan tindakan Sectio Caesaria.
\end{abstract}

Kata kunci: birthing ball; nyeri kala I persalinan; ibu bersalin.

\begin{abstract}
Birthing ball is one of the active birth methods using a pilates ball that helps pregnant women in the first stage. The use of a pilates ball by doing movements such as sitting on a ball and rocking, makes labor progress, provides a sense of comfort and, and increases the secretion of endorphins due to the flexibility and curvature of the ball. stimulate hip receptors. The purpose of this community service is to provide counseling and training about birth balls. The methods used include lectures/delivery of material using leaflets, practicum or direct training to participants and questions and answers to support mother's knowledge about birthing ball therapy. The results of the service activities are evidenced by the activeness of the participants in this activity, the implementation of the activities has been able to increase the knowledge of maternity mothers in reducing pain in the first stage of labor, can manage pain during contractions and maternal discomfort such as excessive anxiety and manage breathing and can reduce back pain, out of breath. The results of this activity have a very positive impact on the delivery process for mothers who are born normally or vaginally without any intervention by performing Sectio Caesaria.
\end{abstract}

Keywords: birthing ball; pain in the first stage of labor; mother gave birth.

\section{PENDAHULUAN}

Kala I persalinan terdapat 2 tahap yaitu fase laten dan fase aktif. Pada fase ini, nyeri kontraksi seperti kram berasal dari distensi jaringan rahim dan pelebaran serviks, meluas melalui saraf tulang belakang ke daerah perut dan daerah lumbisakral. Sebagian besar ibu hamil menunjukkan nyeri saat melahirkan sebagai nyeri yang paling dahsyat yang pernah mereka rasakan. Data WHO tahun 2015 mencatata bahwa setiap hari terdapat 830 ribu wanita yang meninggal dunia disebabkan komplikasi kehamilan serta persalinan(WHO, 2015). Angka Kematian Ibu (AKI) pada tahun 2015 masih tinggi yaitu sebesar 305/100.000 kelahiran hidup.

Data SDKI 2017 menyebutkan bahwa komplikasi saat persalinan disebabkan oleh 
partus lama (41\%) (Kemenkes RI, 2017). Nyeri persalinan dapat menimbulkan stres yang menyebabkan pelepasan hormon yang berlebihan seperti katekolamin dan steroid. Hormon ini dapat menyebabkan terjadinya ketegangan otot polos dan vasokonstriksi pembuluh darah. Hal ini dapat mengakibatkan penurunan kontraksi uterus, penurunan sirkulasi uteroplasenta, pengurangan aliran darah dan oksigen ke uterus, serta timbulnya iskemia uterus yang membuat impuls nyeri bertambah banyak (Sumarah, 2009).

Penelitian yang dilakukan oleh Gau et al. (2011), Membuktikan bahwa nyeri persalinan dan manajemen pengelolaan nyeri tetap menjadi perhatian utama bagi wanita, Keluarga dan Penyedia layanan Kesehatan. Hal ini penting bagi pemberi pelayanankesehatan untuk selalu menggunakan tindakantindakan non farmakologi untuk mengurangi rasa nyeri dalam persalinan. Mengingat potensi efek samping pada ibu dan janin, penggunaan metode farmakologi berupa analgesik dan anestesi memungkinkan untuk tidak menjadi pilihan pertama untuk persalinan. Banyak wanita bersalin yang berkeinginan untuk menghindari nyeri dengan meminimalkan penggunaan metode farmakologi.

Salah satu metode penggunaan active birth yang telah dilakukan di Indonesia adalah penggunaan birth ball dan hypnobirthing sebagai bentuk upaya pemberian asuhan sayang ibu dalam membantu proses persalinan yang evidance base. Birthball merupakan salah satu metode active birth menggunakan bola pilates yang membantu ibu inpartu kala I. Penggunaan bola pilates dengan berbagai posisi untuk membantu mempercepat lamanya inpartu kala I. Dengan melakukan gerakan seperti duduk dibola dan bergoyang-goyang, sehingga membuat kemajuan persalinan, memberikan rasa nyaman dan, serta meningkatkan sekresi endoprin disebabkan kelenturan dan kelengkungan bola merangsang reseptor dipanggul (Souza, 2016)

Penggunaan birth ball selama persalinan mencegah ibu dalam posisi terlentang secara terus-menerus. penggunaan birth ball pada intrapartum memberi kontribusi dalam meningkatkan efikasi diri ibu selama persalinan dan mengurangi rasa sakit sebanyak $60 \%$ melaporkan penurunan tingkat nyeri setelah menggunakan birth ball, $8 \%$ melaporkan nyeri yang lebih dari sebelumnya, $26 \%$ melaporkan tidak ada perubahan dalam tingkat nyerinya (Gau et al., 2011).

Tujuan dari pengabdian masyarakat ini adalah memberikan penyuluhan dan pelatihan tentang birth ball.

\section{METODE}

1. Ceramah dan Diskusi

Kegiatan Pengabdian Masyarakat ini dilakukan langsung di Ruang Bersalin RSUD Kota Mataram pada ibu inpartu (ibu yang ingin bersalin) pada kala I persalinan mulai tanggal 2-30 oktober 2021 dengan jumlah responden 10 orang, setiap pasien yang datang (inpartu) kemudian dilakukan informed consent untuk diberikan materi dan praktik terapi birthing ball pada ibu untuk mengurangi nyeri yang dirasakan menjelang persalinan. Kegiatan selanjutnya diskusi dan tanya jawab untuk memperdalam pemahaman ibu bersalin terkait permasalah atau rasa nyeri yang dirasakan dengan Praktikum/Demonstrasi. Praktikum disini adalah pemateri memberikan tutorial bagaimana cara terapi birth ball. Dan dampingi oleh suami dari ibu bersalin tersebut.

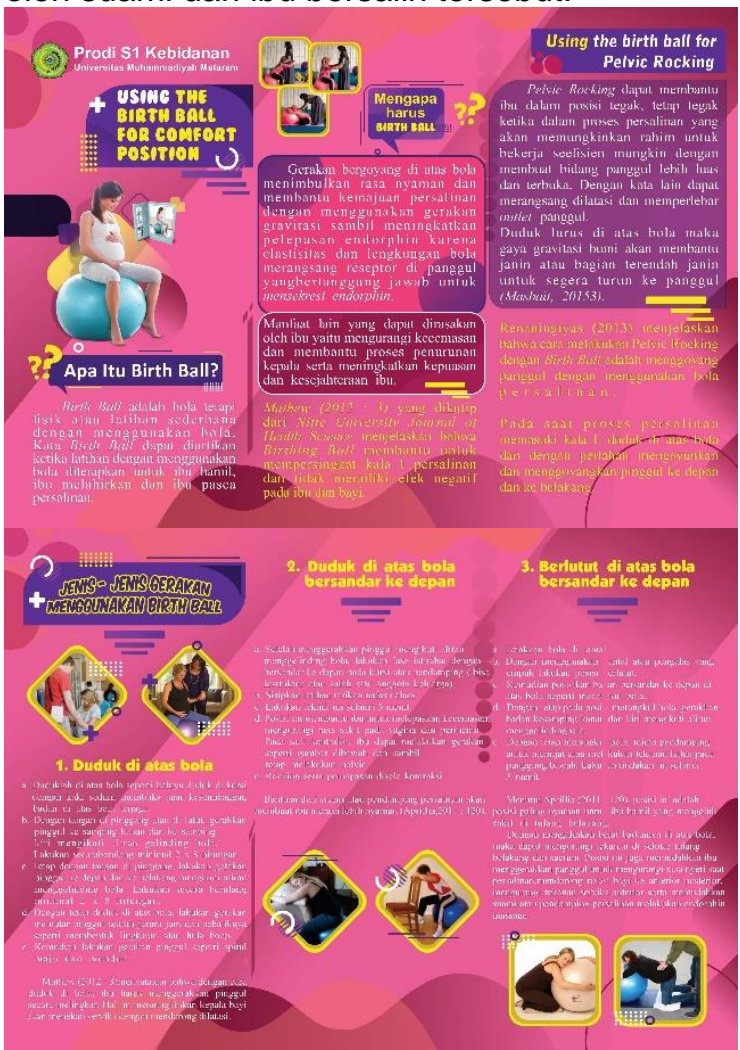

Gambar 1. Leaflet Birthing Ball (Penyuluhan)

Gambar 1 menunjukan leaflet yang digunakan dalam penyampaian materi kepada ibu bersalin, leaflet diberikan untuk kemudian dibaca kembali oleh ibu maupun suami. 


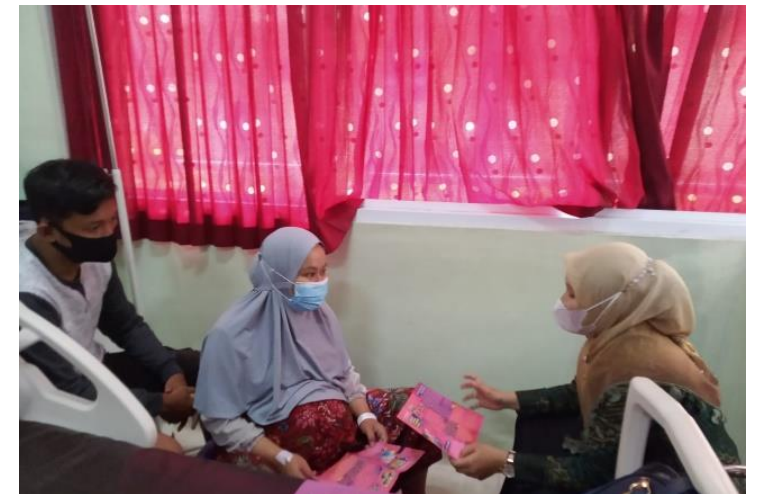

Gambar 2. Pemberian materi (Penyuluhan)

Gambar 2 menunjukkan proses pelaksanaan awal kegiatan pengabdian bersama mitra dengan memberikan penyuluhan terkait pengertian, manfaat dan jenis gerakan terapi birthing ball untuk mengurangi nyeri persalinan.

\section{Metode Praktik}

Pada metode ini sebelum memulai gerakan birthing ball, dilakukan persetujuan terhadap peserta (Informed Consent) terkait beberapa gerakan yang diberikan.

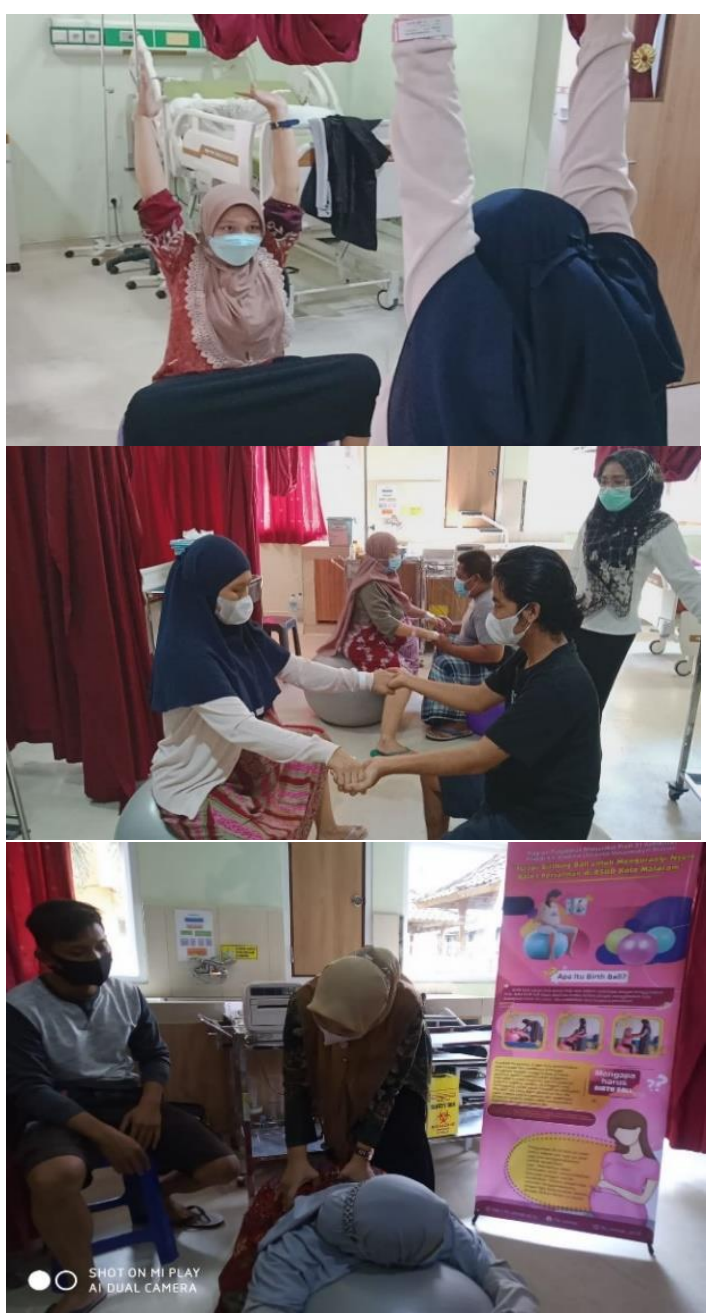

Gambar 3. Demonstrasi/Praktik Birthing Ball
Gambar 3 menunjukkan kegiatan inti pelaksanaan pengabdian bersama mitra terkait gerakan birthing ball.

3. Metode Evaluasi

Pada metode evaluasi dilakukan post test terkait pengetahuan ibu tentang terapi birthing untuk mengurangi nyeri persalinan.

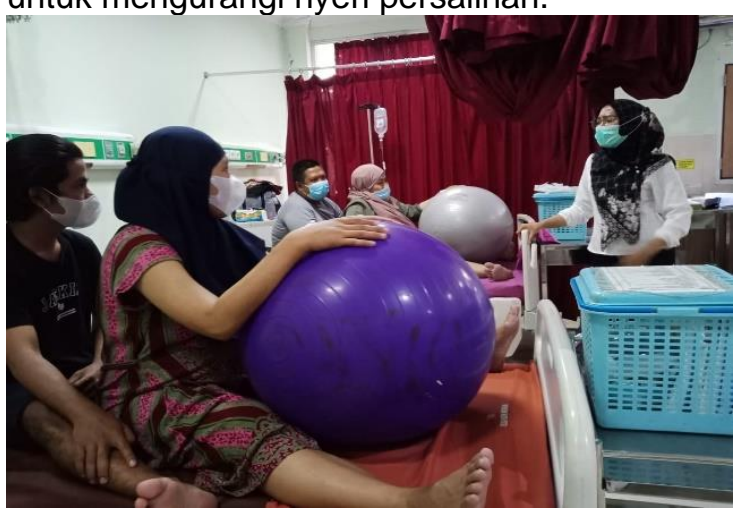

Gambar 4. Tahap evaluasi dan dilakukan post test pada ibu bersalin.

\section{HASIL DAN PEMBAHASAN}

Hasil yang dicapai mengacu pada indikator keberhasilan jangka panjang/pendek, selama pelaksanaan kegiatan pengabdian masyarakat yang dapat dilihat dari kesesuaian jenis dan jumlah luaran yang telah dihasilkan serta presentase hasil terhadap keseluruhan target kegiatan. Tentunya dalah pelaksaaan kegiatan yang telah dilakukan terdapat perubahan kegiatan maupun penambahan kegiatan akan tetapi hal tersebut dapat diselesaikan dengan koordinasi dan konsultasi bersama pihak-pihak terkait. Hasil yang dicapai selama pelaksanaan kegiatan ialah "Penurunan Nyeri Kala I Persalinan".

Berdasarkan pelaksanaan kegiatan pengabdian yang telah dilakukan selama 1 bulan dengan melihat indikator keberhasilan jangka pendek dapat dilihat pada Gambar diagram tersebut. Hasil tersebut menunjukkan bahwa sebagian besar ibu memahami dari materi yang disampaikan oleh tim mengenai birthing ball yang dapat meminimalisir nyeri haid pada kala I persalinan. Berikut ini merupakan grafik hasil pelaksanaan sebelum dan setelah pelaksanaan kegiatan pengabdian masyarakat: 


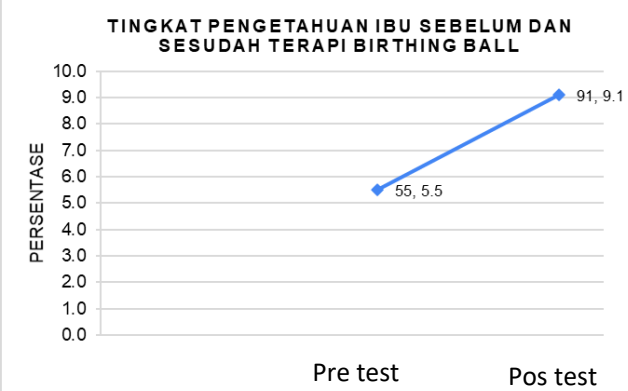

Gambar 5. Diagram sebeleum dan sesudah terapi birthing ball

Gambar 5 di atas menunjukkan bahwa terjadi peningkatan pengetahuan sebelum dan setelah kegiatan, dari 55\% meningkat menjadi $91 \%$.

Karakter tersebut antara lain: mau mendengarkan, empati, suka menolong (tidak egois), proaktif, kreatif dalam menyelesaikan masalah dan kesediaan untuk memikirkan masa depan dengan lebih jelas (Prakoso \& Wahyuni, 2015). Selain itu timbul kemampuan baru dalam aspek psikososial yang selama ini kurang berkembang yaitu memahami diri dan orang lain serta mau terlibat dalam masalah yang dihadapi orang lain.

\section{SIMPULAN DAN SARAN}

Berdasarkan implementasi kegiatan pengabdian dapat disimpulkan bahwa (a) Pelaksanaan kegiatan ini telah mampu meningkatkan pengetahuan ibu bersalin dalam mengurangi nyeri pada kala I persalinan, (b) Dapat mengelola rasa nyeri saat kontraksi dan ketidaknyaman ibu seperti rasa cemas berlebih dan mengelola pernafasan, (c) Dapat mengurangi sakit punggung, sesak nafas. Hasil kegiatan ini sangat berdampak positif pada proses persalinan ibu yang lahir dengan normal atau pervaginam tanpa adanya intervensi dilakukan tindakan Sectio Caesaria.

\section{UCAPAN TERIMAKASIH}

Penulis mengucapkan terimakasih kepada Rektor Universitas Muhammadiyah Mataram, Ketua. LPPM, Dekan Fakultas IImu Kesehatan, Universitas Muhammadiyah Mataram yang memberikan support baik moril dan materil sehingga program pengabdian kepada masyarakat ini dapat terlaksana dengan baik. Kami juga mengucapkan terima kasih yang sebesar-besarnya kepada Dekan dan Kaprodi yang telah menfasilitasi pelaksanaan kegiatan pengabdian kepada masyarakat dapat terlaksana dengan baik.

\section{DAFTAR RUJUKAN}

Darma, I. Y., \& Abdillah, N.(2020). Penerapan Teknik Active Birth Menggunakan Birth Ball Terhadap Kemajuan Persalinan
Kala I Pada Ibu Bersalin. Jurnal IImu Kesehatan (JIK), 4(2).

Dewi, P. I. S., Aryawan, K. Y., \& Ariana, P. A. (2020). Intensitas Nyeri Persalinan Kala I Fase Laten Pada Ibu Inpartu Menggunakan Birth Ball Exercise. Jurnal Keperawatan Silampari 2(3), 456-465.

Gau, M. L., Tian S. H., Chang C. Y., \& Lin K. C., (2011). Effects of Birth Ball Exercise on Pain and Self-Efficacy during childbirth: A Randomised Controlled Trial in Taiwan, Midwifery, Taiwan. 27(6) 293300

Hermina, Widya, C., dan Wirajaya, A. (2015), The Conny Method : Menjalani Kehamilan dan Persalinan dengan Tenang, Nyaman, Bahagia, serta Penuh Percaya Diri. Gramedia, Jakarta. Kemenkes RI. Survei Demografi dan Kesehatan Indonesia (SDKI)., (2017).

Mander, R. (2012), Nyeri Persalinan, Penerbit EGC, Jakarta.

Mutoharoh, S., Indriyani, E., \& Kusumastuti, K. (2020). Pengaruh Terapi Birth Ball Terhadap Proses Persalinan, Jurnal Ilmiah Kesehatan 13(1), 285288.

Matthew, A., (2012), Comparative Study On Effect Of Ambulation and Birthing Ball On maternal And Newborn Outcome Among Primigravida Mothers In selected Hospitals In Mangalore, NUJHS, India. Oktifa,(2012), Birth Ball, Seminar Akhir Departemen Maternitas, PSIK, FK Universitas Brawijaya, Malang.

Sumarah, (2009). Perawatan lbu Bersalin: Asuhan Kebidanan pada Ibu Bersalin. Fitramaya, Yogyakarta.

Sari, P.(2018), Nyeri Persalinan. STIKes Majapahit Mojokerto, Mojokerto

Souza, J.(2016). Maternal Position During the First Stage of Labor: a systematic riview. Reproductive Health, 3(10).

Yudiyanta, Novita, K., \& Wahyu, N. R. (2015). Assessment Nyeri. Jurnal Kesehatan, 42(3).

WHO. Global Health Observatory (GHO) Data : Maternal Mortality. , (2015).

WHO. (2018). Intrapartum care for a positive childbirth experience. 